\title{
COMMENT
}

\section{Reforming Environmental Law $\dagger$}

\author{
Bruce A. Ackerman* \\ Richard B. Stewart**
}

In 1971, Ezra Mishan brilliantly satirized the views of a Dr. Pangloss, who argued that a world of largely unregulated pollution was "optimal" because cleanup would involve enormous transaction costs. ${ }^{1}$ Less than 15 years later, Professor Latin uses the same Panglossian argument to rationalize the current regulatory status quo. ${ }^{2}$ He not only accepts but endorses our extraordinarily crude, costly, litigious and counterproductive system of technology-based environmental controls. Like Mishan's Pangloss, he seems to believe that if it were possible to have a better world, it would exist. Since it does not, the transaction costs involved in regulatory improvement must exceed the benefits. Proposals for basic change accordingly are dismissed as naive utopianism.

What explains this celebration of the regulatory status quo? As critics of the present system, we believe this question to be of more than academic interest. The present regulatory system wastes tens of billions of dollars every year, misdirects resources, stifles innovation, and spawns massive and often counterproductive litigation. There is a variety of fundamental but practical changes that could be made to improve its environmental and economic performance. Why have such changes not been adopted? Powerful organized interests have a vested stake in the

$\dagger$ We are grateful to Errol Meidinger for his thoughtful comments on an earlier draft.

* Beekman Professor of Law \& Philosophy, Columbia University.

** Byrne Professor of Administrative Law, Harvard University.

1. Mishan, Pangloss on Pollution, 73 SwEd. J. Econ. 1 (1971). While tempted to emulate Mishan, we have (recognizing our comparative disadvantage) eschewed satire and have chosen to present an affirmative program for reform.

$\rightarrow$ Latin, Ideal Versus Real Regulatory Efficiency: Implementation of Uniform Standards and "Fine-Tuning" Regulatory Reform, 37 Stan. L. REv. 1267 (1985). 
status quo. The congressional committees, government bureaucracies, and industry and environmental groups that have helped to shape the present system want to see it perpetuated. ${ }^{3}$ But the current system is also bolstered by an often inarticulate sense that, however cumbersome, it "works," and that complexity and limited information make major improvements infeasible.

Professor Latin has performed an important service in providing an articulate, informed, and sophisticated exposition of this view. By developing and making transparent the arguments that might justify the status quo, he has made it easier to assess their merits. If, as we believe, those arguments lack merit, his sophisticated defense of the status quo may ultimately serve to hasten its demise.

We will not respond to all of the groundless charges that Professor Latin levels at the critics of the current system, ourselves included. We focus instead on the major flaws in his defense of existing law and policy. First, Latin's view is based on a Panglossian interpretation of the status quo. The current system does not in fact "work" and its malfunctions, like those of Soviet-style central planning, will become progressively more serious as the economy grows and changes and our knowledge of environmental problems develops.

Second, Latin mistakenly treats economic incentive systems as a form of regulatory "fine-tuning," rather than recognizing them as fundamental alternatives to our current reliance on centralized regulatory commands to implement environmental goals. Moreover, he completely ignores experience showing that economic incentive systems are feasible and effective.

Third, Latin ignores the increasingly urgent need to improve the process by which Congress, the agencies, and the courts set environmental goals. He is mesmerized by decisionmaking costs, ignoring the great social benefits flowing from a more intelligent and democratically accountable dialogue on environmental policy. We deal with each of these points in turn.

\section{The Existing System}

The existing system of pollution regulation, which is the focus

3. See generally Stewart, The Discontents of Legalism: Interest Group Relations in Administrative Regulation, 1985 Wis. L. REv. 655. The forces favoring as well as those opposing reform are examined in Weidinger, On Explaining the Development of "Emissions Trading" in U.S. Air Pollution Policy, 7 Law \& Pol'y 457 (1985). 
of Latin's defense, is primarily based on a Best Available Technology (BAT) strategy. If an industrial process or product generates some nontrivial risk, the responsible plant or industry must install whatever technology is available to reduce or eliminate this risk, so long as the costs of doing so will not cause a shutdown of the plant or industry. BAT requirements are largely determined through uniform federal regulations. Under the Clean Water Act's BAT strategy, the EPA adapts nationally uniform effluent limitations for some 500 different industries. A similar BAT strategy is deployed under the Clean Air Act for new industrial sources of air pollution, new automobiles, and industrial sources of toxic air pollutants. ${ }^{4}$ BAT strategies are also widely used in many fields of environmental regulation other than air and water pollution, which are the focus of Latin's analysis. ${ }^{5}$

BAT was embraced by Congress and administrators in the early 1970 s in order to impose immediate, readily enforceable federal controls on a relatively few widespread pollutants, while avoiding widespread industrial shutdowns. Subsequent experience and analysis has demonstrated:

1. Uniform BAT requirements waste many billions of dollars annually ${ }^{6}$ by ignoring variations among plants and industries in the cost of reducing pollution and by ignoring geographic variations in pollution effects. A more cost-effective strategy of risk reduction could free enormous resources for additional pollution reduction or other purposes.

2. BAT controls, and the litigation they provoke, impose dis-

4. Clean Air Act, 42 U.S.C. $\$ \S 7411(a)(1), 7412,7521$ (a)(3)(A)(i) (1982) (amending 42 U.S.C. $\S \S 1857-58(a)(1976)$ ). Under other portions of the Clean Air Act, regulation of existing industrial sources of certain widespread pollutants is based, in theory, on the achievement of uniform federal air quality standards, rather than available technology. See id. $\$ \$ 7409,7410$. In practice, however, the controls imposed on sources in regions that do not comply with the federal air quality standards are based on "reasonably available control measures"-a form of BAT. See id. $\S 7502$ (b)(2).

5. Examples include control of low-level radioactive emissions from normal operation of nuclear power plants and standards for treatment and disposal of toxic substances under the Resource Conservation and Recovery Act. Resource Conservation and Recovery Act, 42 U.S.C. $\S \S 6901-87$ (1982). Rather than rely on uniform standards requiring that a category of plants or products meet BAT requirements, some environmental regulatory programs use case-by-case screening of particular products or development projects under open-ended criteria such as "unreasonable risk." See Stewart, Regulation, Innovation and Administrative Law: A Conceptual Framework, 69 CAlif. L. REv. $1259,1263-66$ (1981). While our proposals for reform focus on air and water pollution control, we consider briefly their possible application to these other areas of environmental law. See note 39 and text accompanying notes 63-64 infra.

6. See text accompanying notes 10-16, infra. 
proportionate penalties on new products and processes. A BAT strategy typically imposes far more stringent controls on new sources because there is no risk of shutdown. Also, new plants and products must run the gauntlet of lengthy regulatory and legal proceedings to win approval; the resulting uncertainty and delay discourage new investment. By contrast, existing sources can use the delays and costs of the legal process to burden regulators and postpone or "water-down" compliance. BAT strategies also impose disproportionate burdens on more productive and profitable industries because these industries can "afford" more stringent controls. This "soak the rich" approach penalizes growth and international competitiveness. ${ }^{7}$

3. BAT controls can ensure that established control technologies are installed. They do not, however, provide strong incentives for the development of new, environmentally superior strategies, and may actually discourage their development. Such innovations are essential for maintaining long-term economic growth without simultaneously increasing pollution and other forms of environmental degradation. ${ }^{8}$

4. BAT involves the centralized determination of complex scientific, engineering, and economic issues regarding the feasibility of controls on hundreds of thousands of pollution sources.

7. On the differential treatment of old and new sources and resulting implications for investment and productivity, see Crandall, The Political Economy of Clean Air: Practical Constraints on White House Review, in Environmental Policy Under Reagan's Executive Order 205, 215-21 (V. Smith ed. 198 $\rightarrow$ Huber, The Old-New Division in Risk Regulation, 69 VA. L. Rev. 1025 (1983); Stewart, supra note 5. For the impact of domestic environmental regulatory policies on United States international competitiveness, see J. Kalt, The Impact of Domestic Environmental Regulatory Policies on U.S. International Competitiveness, in Energy and Envtl. Pol'y Center, John F. Kennedy Sch. of Gov't, Harv. U., Discussion Paper Series E-85-02, (1985). For suggestive evidence that the current BAT system gives a comparative competitive advantage to large plants within a regulated industry, $\rightarrow$ Pashigian, The Effect of Environmental Regulation on Optimal Plant Size and Factor Shares, 27 J.L. \& ECoN. 1 (1984).

8. See J. Krier \& E. Ursin, Pollution and Policy 24-27 (1977); Stewart, supra note 5. In attacking the treatment of innovation in the latter work, Latin wrongly suggests that it advocates sacrifice of environmental objectives in favor of market investment and productivity gains ("economic innovation"). As Stewart's article makes quite clear, economic incentives are also needed to promote innovation in the development and adoption of environmentally superior technologies ("social innovation"). In contrast to BAT, market incentives allow the two forms of innovation to complement each other, encouraging new investments that are at the same time environmentally and economically superior.

For a more optimistic view of the ability of a BAT approach to stimulate social innovation, see Ashford, Ayres \& Stone, Using Regulation to Change the Market for Innovation, 9 HARV. ENVTL. L. Rev. 419 (1985). 
Such determinations impose massive information-gathering burdens on administrators, and provide a fertile ground for complex litigation in the form of massive adversary rulemaking proceedings and protracted judicial review. Given the high costs of regulatory compliance and the potential gains from litigation brought to defeat or delay regulatory requirements, it is often more cost-effective for industry to "invest" in such litigation rather than to comply. ${ }^{9}$

5. A BAT strategy is inconsistent with intelligent priority setting. Simply regulating to the hilt whatever pollutants happen to get on the regulatory agenda may preclude an agency from dealing adequately with more serious problems that come to scientific attention later. BAT also tends to reinforce regulatory inertia. Foreseeing that "all or nothing" regulation of a given substance under BAT will involve large administrative and compliance costs, and recognizing that resources are limited, agencies often seek to limit sharply the number of substances on the agenda for regulatory action. ${ }^{10}$

This indictment is not idle speculation, but the product of years of patient study by lawyers, economists, and political scientists. ${ }^{11}$ There are, for example, no fewer than 15 careful efforts

9. See Stewart, supra note 5; R. Melnick, Regulation and the Courts: The Case of the Clean Air ACt 193-238 (1983).

10. See Harrison, Haig \& Nichols, Benefits Assessment and Environmental Regulation: Case Studies of Hazardous Pollutants, in Energy and Envtl. Pol'y Center, John F. Kennedy Sch. Of Gov't, Harv. U., Discussion Paper Series E-83-07 (1983); Dorfman, The Lessons of Pesticide Regulation, in Reform of Environmental Regulation 13 (W. Magat ed. 1982); Crandall \& Portney, Environmental Policy, in Natural Resources and the Environment: The Reagan Approach 48-49, 72-73 (R. Portney ed. 1984).

11. For an up-to-date review of relevant sources, see the bibliographies at the end of each chapter compiled by T. Tietenberg, Emissions Trading: AN Exercise in ReForming Pollution Policy (1985). The development of the reformist critique may be traced in Environmental Policy Under Reagan's Executive Order, supra note 7; Natural Resources and the Environment: The Reagan Approach, supra note 10; R. Crandall, Controlling Industrial Pollution: The Economics and Politics of Clean Air (1983); R. Melnick, supra note 9; R. Noll \& B. OWen, supra note 3; InCentive Arrangements for Environmental Protection: A Critical Examination (T. Schelling ed. 1983); W. Magat, supra note 3; L. Lave, Strategy of Social Regulation: Decision Frameworks for Policy (1981); B. Ackerman \& W. Hassler, Clean Coal/ Dirty Air (1981); J. Krier \& E. Ursin, supra note 8; W. Baumol \& W. Oates, The Theory of Environmental Policy (1975); B. Ackerman, S. Rose-Ackerman, J. Sawyer \& D. Henderson, The Uncertain Search for Environmental Quality (1974); J. Dales, Pollution, Property and Prices (1968); A. Kneese \& B. Bower, Managing Water Quality: Economics, Technology and Institutions (1968); Stewart, Economics, Environment, and the Limits of Legal Control, 9 HaRv. EnvTL. L. REv. 1, 7 (1985); Stewart, supra note 5; Krier, The Irrational National Air Quality Standards: Macro-and Micro-Mistakes, 
to estimate the extra cost burden generated by a wide range of traditional legalistic BAT systems used to control a variety of air and water pollutants in different parts of the country. Of the twelve studies of different air pollutants ${ }^{12}$-ranging from particulates to chlorofluorocarbons-seven indicated that traditional forms of regulation were more than $400 \%$ more expensive than the least-cost solution; four revealed that they were about $75 \%$ more expensive; one suggested a modest cost-overrun of $7 \% .^{13}$

22 U.C.L.A. L. Rev. $323(197 \rightarrow$ Rose-Ackerman, Effluent Charges: A Critique, 6 Can. J. ECoN. 512 (1973).

12. For an up-to-date review of empirical research, along with a table that usefully summarizes the results of eleven of the air pollution studies, see $T$. TIETENBERG, supra note 11 , at $39-52$.

In addition to the 11 studies summarized by Tietenberg, some excellent unpublished work by McGartland and Oates. See McGartland \& Oates, Marketable Permits for the Prevention of Environmental Deterioration, - J. of Envtl. Econ. \& MGMT. - (198-) (forthcoming). This study estimates that traditional regulation in the Baltimore area is at least twice as expensive as a least-cost approach. We have therefore counted it among the four studies we have placed in the second of the three crude categories presented in the text.

13. This was the study of sulfate pollution in Los Angeles. Hahn \& Noll, Designing a Market for Tradable Emission Permits, in W. Magat, supra note 3, at 39-52. Two important factors help account for the anomalous character of the Hahn and Noll findings:

First, in contrast to other areas, the command-and-control strategy in California did not include scrubbers, a very expensive approach. Had California required scrubbers, the potential cost savings would have been higher.

Another reason, of more general applicability, is that the amount of control required [to reach air quality objectives in Los Angeles] is so great that every source is forced to control as much as is economically feasible. By definition, little further control can be undertaken. Therefore . . . the divergence between the command-and-control and least-cost allocation would be small.

T. Tietenberg, supra note 11 , at 45 . It should be noted that existing federal law now requires the installation of scrubbers on all new coal-burning power plants in Los Angeles. See B. Ackerman \& W. Hassler, supra note 11, at 101-03. As a consequence, Tietenberg's first point emphasizes the limited power of Hahn and Noll's conclusions even in the extreme situation posed by Los Angeles.

A recent study by Anderson comes to a less certain conclusion. Anderson, Marketable Pollution Permits and Acid Rain Externalities, 16 CAN. J. Econ. 704 (1983). While it finds that marketable rights schemes could generate significant savings in reaching Cleveland's local sulfur dioxide goals, it reaches a more equivocal conclusion once Cleveland's contribution to the larger North American acid rain problem is taken into account. Given Cleveland's strategic geographic location in the Midwest, any plausible solution to acid rain would require all its polluters to treat at very high levels-so high that the cost difference between marketable rights and a more traditional system would be substantially reduced. In respect to its contribution to acid rain, then, Cleveland seems similar to the case of Los Angeles discussed by Hahn and Noll.

Of course, Cleveland is but one of the many sources of the acid rain problem experienced by Canada and the northeastern United States. Unfortunately, however, Anderson has not yet moved beyond Cleveland to study the cost-saving potential of an acid rain marketable rights scheme for the entire North American acid rain control region. 
Three studies of water pollution control in five different watersheds also indicate the serious inefficiency of traditional forms of command-and-control regulation. ${ }^{14}$ These careful studies of selected problems cannot be used to estimate precisely the total amount traditional forms of regulation are annually costing the American people. ${ }^{15}$ Nonetheless, very large magnitudes are at stake. Even if a reformed system could cut costs by "only" onethird, it could save more than $\$ 15$ billion a year from the nation's annual expenditure of $\$ 50$ billion on air and water pollution con-

Telephone conversation (September 17, 1985). Thus, his study does not permit any firm conclusion on the cost-saving potential of a marketable rights scheme in the regulatory response to the acid rain problem. As a consequence, we have omitted it from the studies summarized in the text.

14. These water studies are somewhat less suggestive than are the air studies. They all have to do with the removal of a single (albeit important) water pollutant: biochemical oxygen demand. Moreover, they do not expressly deal with the precise form of BAT regulation actually used under the present Clean Water Act. Instead, the studies investigate a more primitive form of regulation that does not, like BAT, require different cutbacks from different industries depending on the best available technology in each economic sector. Instead, the traditional regulatory approach used as a benchmark in the water studies simply requires all dischargers, regardless of industry, to cut back wasteloads proportionally to reach water quality objectives. This proportionate reduction would be equivalent to BAT only if the best available technology in every industry permits all industries to cut back by the same percentage. While BAT often does lead to this result, the proportionality assumption invoked by all existing water pollution studies can only serve as a crude approximation of BAT's economic impact. Nonetheless, the existing data does suggest the possibility of substantial savings by abandoning BAT, though the overruns are somewhat less substantial than those suggested by the air studies. Four of the computer studies suggest that traditional regulation is more than twice as expensive as the least-cost program; six suggest an overrun in the $40-60 \%$ range; while four indicate extra costs of $12-40 \%$. A summary of these studies appears in $T$. TietenberG, supra note 11 , at $42-43$.

15. Speaking broadly, the empirical estimates we have summarized in the text are generated by procedures that overestimate BAT's short-term costs, while underestimating its long-term costs. Thus, on the one hand, the computer models do not generally take into account that many polluters have already sunk capital into treatment facilities that would never have been required under a cost-minimizing regulatory scheme. This leads to an overestimate of the short-term savings of regulatory reform because it ignores that some existing equipment might be operated cheaply in the short run, however inefficient it was to install in the first place. On the other hand, existing cost estimates are generated by static models that do not take into account the BAT regime's depressive effect on the rate of pollution control innovation. See text accompanying notes 18-19 infra. As a consequence, even the very large cost-overruns presented in the text underestimate likely realities 10 or 20 years in the future. These and other useful interpretive points may be found in Professor Tietenberg's recent review of the evidence. See T. Tietenberg, supra note 11, at 38-53. We do not think a lengthy elaboration of his discussion is necessary to make our basic point: By even the most conservative reckoning, the economic savings promised by a successful reform are substantial indeed. 
trol alone. ${ }^{16}$

While Latin entirely fails to address this evidence, he does not seriously contest the economic wastefulness of the current system's excessive compliance costs and penalties on new investment. He simply ignores the last three points in our indictment, even though they have been well developed in the literature. Instead, Latin spends all his time castigating all reform proposals as unrealistic. In his view, reformers characteristically propose utopian efforts at administrative "fine-tuning" that would in practice lead to a bureaucratic nightmare, making the present system seem benign by comparison.

We do not accept this despairing view. To explain why, however, we must correct an analytic deficiency in Latin's critique. The various reforms rejected in his article have little in common with one another-except that they all represent departures from BAT. Indeed, it is a sign of Latin's deep commitment to the status quo that, simply because they depart from BAT, he thinks of them as if they were all variations on the problem of "fine-tuning" that he decries. But "fine-tuning" is much too diffuse a notion on which to base an analysis of the reform agenda. Some of our proposals involve reform of the criteria and procedures which Congress, agencies, and the courts use in setting environmental goals; others involve reform of the means by which the goals (whatever they may be) are implemented in the real world. Latin's indiscriminate condemnation of "fine-tuning" fails to distinguish systematically between these two types of proposals. In this, as in so much else, his critique is faithful to the BAT system, which also conflates means and ends, preventing the intelligent assessment of either. If, however, we are to move beyond the status quo, it is best to treat these two different kinds of structural reform separately, beginning with the implementation problem and concluding with the question of goal-setting. ${ }^{17}$

16. See Office of Policy Planning and Evaluation, U.S. EPA, The Cost of Clean Air and Water (1984) (estimating expenditures to comply with federal air and water pollution control expenditures in the ten years 1981-1990 at $\$ 525$ billion (in constant 1981 dollars)). Moreover, we also think that our reforms are applicable to many other kinds of pollution as well. See notes 39-40 infra and accompanying text.

17. While, as we hope to show, this simple means-end schema clarifies the reform agenda, it can lead to distortions of its own. In particular, it may be used to blind one to the complex ways in which a particular implementation scheme shapes the standardsetting process over time-and vice versa. See Roberts \& Stewart, Book Review, 88 HaRv. L. Rev. 1644, 1661-62 (1975). We shall, however, try to be attentive to this very important factor in the ensuing discussion. See notes 44-47 infra and accompanying text. 


\section{IMPLEMENTATION}

A BAT system has an implicit environmental goal: achievement of the environmental quality level that would result if all sources installed BAT controls on their discharges. The usual means for implementing this goal are centralized, industry-uniform regulations that command specific amounts of cleanup from specific polluters. When a polluter receives an air or water permit under existing law, the piece of paper does not content itself, in the manner of Polonius, with the vague advice that he "use the best available technology." Instead, the permit tries to be as quantitatively precise as possible, telling each discharger how much of the regulated pollutants he may discharge. ${ }^{18}$

Although Latin condemns us as unrealistic, our reforms build upon, rather than abandon, this basic permit system. Indeed, we have only two, albeit far-reaching, objections to the existing permit mechanism. First, existing permits are free. This is bad because it gives the polluter no incentive to reduce his wastes below the permitted amount. Second, they are non-transferable. This is bad because polluter $\mathrm{A}$ is obliged to cut back his own wastes even if it is cheaper for him to pay his neighbor B to undertake the extra cleanup instead.

Our basic reform would respond to these deficiencies by allowing polluters to buy and sell each other's permits-thereby creating a powerful financial incentive for those who can clean up most cheaply to sell their permits to those whose treatment costs are highest. This reform will, at one stroke, cure many of the basic flaws of the existing command-and-control regulatory systems discussed earlier.

A system of tradeable rights will tend to bring about a least-

18. While the text describes the existing system's implicit regulatory objective, in fact the process of writing, monitoring, and enforcing permits is the Achilles heel of the BAT strategy. See text accompanying notes 28-30 infra. While officials in Washington promulgate regulations that are supposed to govern the operation of every plant in an industry, such regulations must be adapted to the specific and varying conditions of different plants throughout the nation. Thus, the actual writing of permits is often accomplished by low-level state or federal field personnel. These permits are often vague and obsolescent. Pedersen, Why the Clean Air Act Works Badly, 129 U. PA. L. Rev. 1059 (1981). Moreover, enforcement of permit conditions is often ineffective. See U.S. GEN. Acct. Off., Wastewater Dischargers Are Not Complying with EPA Control PerMITs (1983); Roberts \& Farrell, The Political Economy of Implementation: The Clean Air Act and Stationary Sources in Approaches To Controlling Air Pollution 152 (A. Friedlander ed. 1978). See text accompanying notes 19-33 infra for the reasons we believe that a reformed system of transferable permits will tend to alleviate these problems. 
cost allocation of control burdens, saving many billions of dollars annually. ${ }^{19}$ It will eliminate the disproportionate burdens that BAT imposes on new and more productive industries by treating all sources of the same pollutant on the same basis. ${ }^{20}$ It will provide positive economic rewards for polluters who develop environmentally superior products and processes. ${ }^{21}$ It will, as we show below, ${ }^{22}$ reduce the incentives for litigation, simplify the issues in controversy, and facilitate more intelligent setting of priorities.

Would allowing the sale of permits lead to a bureaucratic nightmare? Before proceeding to the new administrative burdens marketability will generate, it is wise to pause, as Latin does not, to consider marketability's great administrative advantages.

First, marketability would immediately eliminate most of the information-processing tasks that are presently overwhelming the federal and state bureaucracies. No longer would the EPA be required to conduct endless adversary proceedings to determine the best available control technologies in each major industry of the United States, and to defend its determinations before the courts; nor would federal and state officials be required to spend vast amounts of time and energy in adapting these changing na-

19. An emissions trading system tends to achieve a least-cost allocation of control for all sources by forcing them to pay the same price for pollution. In practice, a regulated emission trading market is likely to deviate somewhat from the perfect market ideal, but substantial cost savings will still be achieved. See T. Tietenberg, supra note 11 , at 50-56.

20. Equal treatment of old and new sources will not necessarily lead, as Latin apparently fears, to shutdowns of old plants. It is true, of course, that old plants may evade clean-up under BAT if their profits are too low to bear the expense. Because of concern over shutdown, they are often allowed to discharge large wasteloads that could otherwise be treated at low cost. The tradeable permits strategy, however, can provide the needed financing for cleanup by enabling the old plant to sell its pollution rights to others. Thus, a marketable rights system may allow old plants to stay in business and clean up. If shutdown does occur, it may be more readily accepted as the product of market forces rather than as a deliberate, isolated government decision.

If the unemployment and dislocation caused by plant shutdowns due to pollution control programs are judged unacceptable, the appropriate response is not, as Latin advocates, to weaken the program or impose disproportionate controls on new sources so as to throttle investment and productivity gains. The appropriate response is remedial: Compensation programs should be designed to deal with unemployment and dislocation.

21. See Levin, Getting There: Implementing the "Bubble" Policy, in Social Regulation: Strategies For Reform 59 (E. Bardach \& R. Kagan eds. 1982); Stewart, supra note 5, at 1309-11, 1332-37; Regulatory Reform Staff, U.S. EPA, Emissions Trading Report (May 10, 1984).

22. See text accompanying notes 31-33 infra. 
tional guidelines to the particular conditions of every important pollution source in the United States. Instead of giving the job of economic and technological assessment to bureaucrats, the marketable rights mechanism would put the information-processing burden precisely where it belongs: upon business managers and engineers who are in the best position to figure out how to cut back on their plants' pollution costs. If the managers operating plant A think they can clean up a pollutant more cheaply than those in charge of plant $B$, they should be expected to sell some of their pollution rights to $\mathrm{B}$ at a mutually advantageous price; cleanup will occur at the least cost without the need for constant bureaucratic decisions about the best available technology. Latin seriously misleads when he describes a marketable permit system as one involving administrative "fine-tuning." To the contrary, it is the existing system of command-and-control regulation that envisions inevitably ill-informed bureaucrats continually "fine-tuning" technological and economic decisions best made by the people operating the plants.

Second, marketable permits would open up enormous financial resources for effective and informed regulation. While polluters would have the right to trade their permits among themselves during the $n$ years ${ }^{23}$ they are valid, they would be obliged to buy new ones when their permits expired at an auction held by the EPA in each watershed and air quality control region. These auctions would raise substantial sums of money for the government on a continuing basis. While no study has yet attempted to make global estimates for the United States as a whole, existing work suggests that auction revenues could well equal the amount polluters would spend in cost-minimizing control activities. ${ }^{24}$ Even if revenues turned out to be a third of this amount, the government would still be collecting more than \$6-10 billion a year. Moreover, it seems reasonable to suppose that Congress would allow the EPA (and associated state agencies) to retain a substantial share of these revenues. Since the

23. All permits would not have to expire at the same time. For a discussion of systems that allow for variable time periods and differential privileges during emergency conditions, see T. Tietenberg, supra note 11, at ch. 7; B. Ackerman, S. Rose-Ackerman, J. Sawyer \& D. Henderson, supra note 11, at 268; J. Dale, supra note 11 , at 95.

24. T. Tietenberg, supra note 11 , at 102-13, contains a comprehensive discussion of existing data. He concludes: "Of the 39 numerical entries [in his summary tables] permit expenditures are at least as great as control costs in 22 cases. . . . Large permit expenditures are the normal, rather than the exceptional, outcome." Id. at 106. 
current EPA operating budget is $\$ 1.3$ billion, ${ }^{25}$ using even a fraction of the auction fund to improve regulatory analyses, research, and monitoring would allow a great leap forward in the sophistication of the regulatory effort-something Latin says he supports, but is unable to find any practical way of achieving. ${ }^{26}$ Given its revenue-raising potential, environmental reform is hardly a politically unrealistic pipe dream. To the contrary, it is only a matter of time before the enormous federal deficit forces Congress and the President to consider the revenue-raising potential of an auction scheme. ${ }^{27}$

Third, the auction system would help correct one of the worst weaknesses of the present system: the egregious failure of the EPA and associated state agencies to enforce the laws on the books in a timely and effective way. Part of the problem stems from the ability of existing polluters to delay regulatory implementation by using legal proceedings to challenge the economic and engineering bases of BAT regulations and permit conditions. But agencies also invest so little in monitoring ${ }^{28}$ that they

25. See Davis, Reagan Boosts EPA Funding, Slashes Interior Spending, 43 CoNG. WEEKLY REP. 255 (1985). This figure excludes municipal water treatment subsidies and Superfund cleanup, but includes all regulatory programs, including pesticides, hazardous waste, drinking water, and chemicals as well as air and water pollution regulation.

26. See Latin, supra note 1 , at 1279.

27. Not that the political fight for an auction will be an easy one. Apart from thoughtful people like Latin, who are committed by conviction to the status quo, our market reform will be opposed by businesses who (despite their promarket rhetoric) will predictably resist the prospect of buying pollution rights after all these years of polluting for free. Nonetheless, we believe that the reformist claim that the air and water of America belong to the people, and that polluters should pay if they wish to use it for limited periods, has enormous popular appeal. While it is possible to design efficient auction systems that ameliorate, or eliminate entirely, the financial burdens imposed upon polluters, see T. TietenberG, supra note 11, at 100-13 (and sources cited therein), we would oppose these schemes on principle. We believe that just as firms are obliged to pay for other raw materials they require for their production process, they should be obliged to pay for the air and water they degrade. (Unlike current proposals to impose new taxes on all industries to finance toxic cleanup, tradeable permits would make sources pay in proportion to their contribution to pollution.)

The only exception we believe justified-for distributional and other reasons-is one for domestic waste processed by municipal sewage authorities. Congress could accommodate this interest by ordering the EPA to give each municipality free permits based on the normal domestic waste produced by the average American. Cities could, of course, then make money by selling these rights to firms if private cleanup is relatively more expensive than public. In addition, Congress might well accommodate individual polluter interests by allowing a transitional period of free use, see note 20 supra, in order to soften adjustment pains and reduce political opposition.

28. Total federal, state, and local expenditure on air quality monitoring averaged only $\$ 44$ million a year during the four fiscal years between 1978 and $1981-.02 \%$ of the 
must rely on polluters for the bulk of their data on discharges. Since polluters are predictably reluctant to report their own violations, the current system perpetuates a Panglossian view of regulatory reality. For example, a General Accounting Office investigation of 921 major air polluters officially considered to be in compliance revealed 200 , or $22 \%$, to be violating their permits; in one region, the number not complying was 52\% ${ }^{29}$ Even when illegal polluters are identified, they are not effectively sanctioned: The EPA's Inspector General in 1984 found that it was a common practice for water pollution officials to respond to violations by issuing administrative orders that effectively legitimized excess discharges. ${ }^{30}$ Thus, while the system may, after protracted litigation, eventually "work" to force the slow installation of expensive control machinery, there is no reason to think this machinery will run well when eventually installed. Although there are many reasons for this appalling weakness in enforcement, one stands out above all others: The present system does not put pressure on agency policymakers to make the large investments in monitoring and personnel that are required to make the tedious and unending work of credible enforcement a bureaucratic reality.

The auction system would change existing compliance incentives dramatically. It would reduce the opportunity and incentive of polluters to use the legal system for delay and obstruction by finessing the complex BAT issues, and it would limit dispute to the question of whether a source's discharges exceeded its permits. It would also eliminate the possibility of using the legal system to postpone implementation of regulatory requirements by requiring the polluter that lost its legal challenge to pay for the permits it would have been obliged to buy during the entire

estimated costs of air pollution control during this period. See Crandall, supra note 7, at 220. Crandall goes on to report:

In 1979 , the GAO reported that as many as 81 percent of all monitoring sites had one or more problems that could affect data reliability. In response, EPA developed a plan to assure that a total of more than five thousand monitors be sited and operated in a reliable fashion by federal, state, and local authorities. By the end of 1981, GAO reported that only about one-half of all monitors met Id. EPA specifications.

29. U.S. Gen. Acct. Off., Improvements Needed in Controlling Major Air Pollution Sources 9 (1979) (Report CEP-78-165).

30. 5 INSIDE EPA Report No. 11, at 6 (March 16, 1984). For other critiques of agency implementation efforts, see Roberts \& Farrell, supra note 18; Crandall \& Portney, supra note 10 at $42-49,69$. 
intervening period of noncompliance (plus interest). ${ }^{31}$

The marketable permit system would also provide much stronger incentives for effective monitoring and enforcement. If polluters did not expect rigorous enforcement during the term of their permits, this fact would show up at the auction in dramatically lower bids: Why pay a lot for the right to pollute legally when one can pollute illegally without serious risk of detection? Under a marketable permit approach, this problem would be at the center of bureaucratic attention. For if, as we envisage, the size of the budget available to the EPA and state agencies would depend on total auction revenues, the bureaucracy's failure to invest adequately in enforcement would soon show up in a potentially dramatic drop in auction income available for the next budgetary period. This is not a prospect that top EPA administrators will take lightly. Monitoring and enforcement will become agency priorities of the first importance. Moreover, permit holders may themselves support strong enforcement in order to ensure that cheating by others does not depreciate the value of the permit holders' investments. ${ }^{32}$

A system of marketable permits, then, not only promises to save Americans many billions of dollars a year, to reward innovative improvements in existing clean-up techniques, and to eliminate the BAT system's penalty on new, productive investment. It also offers formidable administrative advantages. It relieves agencies of the enormous information-processing burdens that overwhelm them under the BAT system; it greatly reduces litigation and delay; it offers a rich source of budgetary revenue in a period of general budgetary stringency; and it forces agencies to give new importance to the critical business of enforcing the law in a way that America's polluters will take seriously. Despite his emphasis on administrative realities, Latin has failed to take any of these advantages seriously. ${ }^{33}$ Instead, he speaks forebodingly

31. In addition, of course, a fine should be imposed if a polluter's discharges exceeded the permits it has acquired. Such a fine should be based not only on the extent of the excess but also its duration: $\$ \mathrm{X}$ per unit of excess emission per day. While noncompliance penalties can be added on to a regulatory approach, see Drayton, Economic Law Enforcement, 4 Harv. EnvTl. L. Rev. 1 (1980), they appear to have played a minor role to date.

32. The opposition of New York taxi companies to competition by gypsy cabs without medallions shows that this is by no means a fanciful prospect.

33. While he mentions the first perfunctorily, he completely ignores the other three. 
of the dangers of "fine-tuning" that the market reform entails. What precisely are these dangers?

The reformed system we have described involves the execution of four bureaucratic tasks. First, the agency must estimate how much pollution presently is permitted by law in each watershed and air quality region. Second, it must run a system of fair and efficient auctions in which polluters can regularly buy rights for limited terms. Third, it must run an efficient title registry in each region that will allow buyers and sellers to transfer rights in a legally effective way. Fourth, it must consistently penalize polluters who discharge more than their permitted amounts.

And that's that. So far as the fourth bureaucratic task is concerned, we have already given reasons to believe that the EPA would enforce the law far more effectively under the new regime than it does at present. So far as the first three management functions are concerned, we think that they are, in the aggregate, far less demanding than those they displace under the BAT system.

Taking the three functions in reverse order, we assume that Professor Latin would agree that a system of title registration is within the range of bureaucratic possibility. In contrast, the second task-running fair and efficient auctions-is a complicated affair, and it is easy to imagine such a system run incompetently or corruptly. Nonetheless, other agencies seem to have done similar jobs in satisfactory fashions: If the Department of Interior can auction off oil and gas leases competently, ${ }^{34}$ we see no reason the EPA could not do the same for pollution rights. Finally, there remains the task of estimating the total allowable wasteload permitted under existing law in each watershed and air control region. If the BAT system functioned properly, these numbers would be easy to obtain. EPA's regional administrators would simply have to add up the allowed amounts appearing in the permits that are in their filing cabinets. We have no illusions, however, about present realities: So much bureaucratic time and energy has been diverted into the counterproductive factfinding tasks generated by the BAT system, and so little attention has been paid to actual discharges, that even the data needed for these simple arithmetic operations may well be incomplete and inadequate. Nonetheless, total permitted emissions in a region

34. We are commenting here on the Department's technical success in running auctions, not on the substantive policies it has pursued in the past or present. 
can be approximated in order to get a system of permits and auctions started. Surely this start-up effort would be less complex than the unending inquiries into available technologies required by the existing system.

We believe, in short, that Latin has confused the novel with the complex in his condemnation of the auction proposal. While it is true that the three new tasks involved in running the reformed system are novel, they seem, in the aggregate, a good deal easier to discharge than the bureaucratic functions they displace. Moreover, what little experience the EPA has had with market approaches supports this conclusion. While Latin completely ignores this important evidence, the fact is that the EPA has effectively discharged the bureaucratic tasks necessary to develop its market-based "bubble" and "tradeoff" control strategies under the Clean Air Act. These strategies create limited markets in pollution rights by: 1) allowing a new source to offset its new emissions by inducing an existing source to reduce its discharges (this is the so-called "tradeoff" policy); 2) allowing an existing source that is expanding to reallocate control burdens among its existing and new units (new source bubble); and 3) allowing existing sources in the same region to reallocate control burdens (state implementation plan bubble). ${ }^{35}$ The use of these innovations was for many years clouded by legal uncertainties until the Supreme Court recently rejected challenges from some environmental groups. ${ }^{36}$ Despite this uncertainty, the Clean Air Act bubble policy alone, in limited use for only a few years, has achieved compliance cost savings of over $\$ 700$ million without any reduction (and in some cases an increase) in pollution control. ${ }^{37}$

More recently, the EPA has successfully instituted and managed a tradeable permit system among refiners in connection with an EPA-mandated phasedown of lead additives in gasoline.

35. See Stewart, supra note 11, at 13-14, and sources cited therein.

36. Chevron, U.S.A., Inc. v. Natural Resources Defense Council, Inc., 104 S. Ct. 2778 (1984).

37. See T. Tietenberg, supra note 11 , at 52-56; sources cited supra note 12 . Like any policy innovation, implementation of bubbles and tradeoffs raises numerous administrative and legal micro-problems. See Liroff, The Bubble Policy and Emissions Trading: The Toil and Trouble of Regulatory Reform (1985). As the Liroff study shows, many of these problems are caused by the effort to graft a limited system of tradeable pollution rights onto an existing regulatory system. Our proposal would entirely replace that system with tradeable rights, eliminating many of the complexities of a hybrid approach. 
Refiners with higher lead-reduction costs buy lead rights from refiners with lower costs. All refiners file quarterly reports showing the lead content of their gasoline, as well as sales and purchases of rights with other refiners. Three-quarters of all refiners participate in purchases and sales of lead rights. The system will save hundreds of millions of dollars compared to uniform BAT commands. ${ }^{38}$

In ignoring this record, it is Latin, not the reformers, who is "short on empiricism." The time is ripe for a market reform of the kind we have just described. Rather than using tradeable emission rights as a limited modification of BAT strategies, the bubble and tradeoff approaches should be generalized to permit regional trading of all air and water pollution permits. Moreover, the tradeable permit strategy should be used to deal with pollution problems-such as acid rain-that are currently unregulated and could be handled efficiently and effectively through economic incentives. ${ }^{39}$

Would a system of marketable rights preclude improvement of environmental quality? By no means. The initial stock of rights can be amortized on a fixed schedule in order to reach a targeted goal, or the government may decide not to reissue existing rights after they expire. ${ }^{40}$ Any such reductions will increase the price of rights by reducing supply. Prices will also automatically tend to rise over time as the economy grows and the demand for rights increases. Under a BAT approach, by contrast, regulators must consistently undertake new, difficult, and unpopular initiatives to impose ever more stringent BAT controls on existing sources in order to accommodate economic growth without increased pollution. The prospect of steady increases in the price of rights will be a powerful incentive- far more powerful than the patchwork efforts at "technology forc-

38. See Office of Policy Planning and Evaluation, U.S. EPA, Costs and Benefits of Reducing Lead in Gasoline: Final Regulatory Impact Analysis (1985).

39. See Stewart, supra note 11 , at 14-15, and sources cited therein. Nor do we see any reason to limit the use of tradeable permits to air and water pollution problems. As we argue in the next section, hazards from toxic chemicals might appropriately be controlled through a system of "risk rights." Under this system, producers of new pesticides or other chemicals would purchase rights from existing producers or compete successfully for rights at one of the regular EPA auctions. Either way, the entry of new producers would force existing producers to reduce existing risk, thereby ensuring that the new product would not increase the total risk from chemicals faced by society.

40. See note 23 supra. 
ing" under the BAT system-for businesses to develop cleaner products and processes.

A more serious objection to our proposal is that it ignores the problem of defining the region within which trades are permitted. The short answer is that the EPA and the States have already divided the nation into several hundred air quality control regions; similarly, the states have delineated the watershed boundaries for pollution control and other water management purposes. ${ }^{41}$ Rather than starting from scratch, our proposal can proceed on the basis of these existing boundaries. Especially in the area of air pollution, however, we have no doubt that existing regional lines have been drawn in a way that is extremely insensitive to ecological realities. ${ }^{42}$ We strongly recommend, therefore, that a reformed statute provide a mechanism for the orderly reexamination of existing regional boundaries-although it may well be wiser to defer this question for five or ten years to allow the EPA to concentrate on the challenges involved in managing the transition to a marketable permit system.

Latin is on stronger ground, we believe, in emphasizing that a reformed implementation system would not easily solve all foreseeable regulatory problems. In particular, the market system we have described could allow the creation of relatively high concentrations of particular pollutants in small areas within the larger pollution control region. In tolerating "hot spots," of course, our reform proposal shares the defects of the existing BAT system, which also generates risk of "hot spots" by imposing the same controls on sources regardless of their location, the size of the human population affected by their discharges, and the nature and vulnerability of affected ecosystems. ${ }^{43}$ Nonetheless, the

41. Most major lake and river systems are the subject of intense water quantity and water quality management under watershed systems established under state law or interstate compacts. We would establish the geographic boundaries of water pollution permit markets by reference to these systems.

42. They typically follow state lines, for example, leading to extremely unwieldly efforts by courts to take interregional impacts into account. See, e.g., Connecticut v. EPA, 656 F.2d 902 (2d Cir. 1981); New England Legal Found. v. Costle, 632 F.2d 936 (2d Cir. 1980) (per curiam).

43. Existing federal laws contain some provisions to prevent excessive local environmental damage from sources that already comply with BAT standards. But as Latin notes, these provisions have not been effectively implemented. We believe that an important reason for this failure is the diversion of bureaucratic energies into BAT determinations. Thus, even in our first-generation proposals for reform, it may be possible to design crude, but useful, mechanisms by which the EPA can realistically respond to "hot 
blindness of both systems to intraregional variation is a serious source of concern. The extensive literature on marketable permits-almost entirely ignored by Latin-points to a variety of feasible means for dealing with the hot spot problem. ${ }^{44}$ We believe that a long-run strategy for institutional reform should strive to take advantage of these more sophisticated market solutions to the problem of intraregional variation. For the present, it will be enough to emphasize our agreement with Latin's caution that administrative feasibility is an important constraint on the degree of sophistication that we may reasonably expect. ${ }^{45}$

The critical question here, however, is not whether our market reform fails to solve problems that the BAT system also fails to solve. It is whether the reformed implementation system will generate new problems that offset its great economic, environmental, and administrative advantages. Curiously, Latin fails to note one potential difficulty that may prove significant. We can foresee situations in which existing polluters might try to manipulate the rights market to deter entry by new firms in a way that is inconsistent with the antitrust laws, by either monopolizing the pollution rights market itself, or using it to block entry by competitors. There is, however, a considerable literature in which problems like this are discussed, ${ }^{46}$ and we ourselves have worried about them. ${ }^{47}$ Neither Latin nor anybody else, however, has offered a list of particular administrative problems that remotely offset the multiple advantages of a system reformed in the manner we have sketched here.

\section{Goals}

We now address reforms that have more to do with the way existing policy goals are established than with the way they are

spots" once it has been liberated from its BAT routines. All we can do here, however, is to flag this problem of statutory design as deserving high priority on the reform agenda.

44. See T. TieTEnBerg, supra note 11 , at $64-86$, and sources cited therein.

45. The need to strengthen regulatory institutions on the regional level is discussed further at text accompanying note 57 infra.

46. See, e.g., T. TIETENBERG, supra note 11 , chs. 4, 6, \& 7 and sources cited therein; Rose-Ackerman, Market Models for Water Pollution Control: Their Strengths and Weaknesses, 25 Pub. Pol'y 383 (1977).

47. B. Ackerman, S. Rose-Ackerman, J. Sawyer, \& D. Henderson, supra note 11 , at 275-81; Stewart, supra note 5, at 1336. Administrative authorities may also have to play a "market-maker" role in the rights market in order to ensure an adequate supply of rights at all times and smooth out price fluctuations, see J. Dales, supra note 11 , at 94-95, although it is possible that private institutions could discharge these functions. 
implemented. Latin writes as if our proposals aimed for a system in which "[d]ecisionmakers must evaluate all relevant ecological circumstances, human impacts, and regulatory costs to identify the "optimal" level of environmental protection in particular controversies or locations." 48 We have never advocated any such utopian scheme; our writings demonstrate that we have been well aware of the problems of limited information and excessive regulatory complexity.

Instead, it is Latin who has fallen into the trap of supposing that the only relevant alternative to the status quo is a fantastic rococo system in which every conceivable form of "fine-tuning" is institutionalized immediately. We reject this view. Rather than imagining reform as one extravagant "great leap forward," we envision a series of steps in an ongoing process of piecemeal improvement. Each element in the reform program can be implemented at a different time and should be evaluated on its own merits. Thus, the market implementation mechanism described in the preceding section was a piecemeal reform based on the allowable pollution loads prevailing under existing law. Even if Latin's critique of "fine-tuning" in the goal-setting process were entirely correct, the merits of the marketable rights program as an implementing mechanism would remain untouched. Similarly, we regard the policymaking proposals we make in this section as a series of discrete steps toward a more democratic, and more enlightened, dialogue on the nature of America's evolving environmental objectives. While some immediate reforms will lay the foundation for further advances, we hope that doubts about the institutional feasibility of some of our long-run proposals will not deflect attention from feasible short-term reforms that promise immediate and substantial improvements.

\section{A. A Short-Term Strategy: Redesigning Statutory Variables}

To focus first on the short-term prospect for clear and present improvement, we begin by provisionally accepting Latin's assertion that administrative and political difficulties in devising nonuniform standards dictate uniform federal environmental objectives throughout the nation, regardless of regional variations. Even if we accept this constraint, we can nonetheless build upon the preceding marketable rights proposal in a way that en-

48. Latin, supra note 1 , at 1275 . 
hances the democratic quality of the policymaking process. At present, the BAT system focuses congressional debate, as well as administrative and judicial proceedings, upon arcane technological and definitional questions which rapidly outstrip the time and energy that most politicians and citizens are willing to spend on environmental matters. In contrast, the marketable permit system will allow the policymaking debate to take a far more intelligible shape. Rather than debating the difference between the "best available control technology" and "lowest achievable emission rate," 49 citizens will be encouraged to focus on a different question when the environmental acts come up for revision: During the next $n$ years, should we instruct the EPA gradually to decrease (or increase) the number of pollution rights by $x$ percent? Environmentalists will, of course, argue for big reductions; others, who are more impressed with the costs of control, will argue for smaller reductions or even selective increases. But at least the congressional debate would be encouraged to focus upon the fundamental question: Speaking broadly, do the American people believe existing environmental objectives are too ambitious (in which case Congress should increase the number of rights), or do they think that Congress should cut back further on pollution by cutting back on the number of rights?

Rather than supposing - as Latin intimates-that such a question should be answered by a cost-benefit analysis, we believe that it is the quintessentially political question that should be answered by the legislative process. The great virtue of the marketable permit program is that it puts the question in an operational form accessible to the general public. An analogy from a very different policy area may be instructive. Imagine that the Department of Labor refused to report an unemployment rate each month. Instead, when it was asked about the employment situation, it inundated its audience with stories about how workers in one or another industry might be displaced or reemployed by one or another technology. While such stories are informative, wouldn't there be a great danger that the general public and Congress would miss the forest for the trees? The preeminent question that generalist decisionmakers can and should answer is

49. See Clean Air Act $\S 165(a)(4), 42$ U.S.C. $§ 7475$ (a)(4) (BAT requirements applicable to new sources in prevention of significant deterioration areas); Clean Air Act $\S 171(3), 42$ U.S.C. $\$ 7501(3)$ (BAT requirements applicable to new sources in nonattainment areas). 
how much overall unemployment is tolerable. And for this purpose, the unemployment rate functions as a key control variable. The same holds true in environmental policy: A vote on a proposal to change the overall number of pollution permits would be a vehicle for the democratic formulation of policy superior to any generated by the existing BAT regulatory system.

To put the point more broadly, we propose the use of a new statutory control variable in the design of our environmental statutes. Rather than speaking in technology-based terms, the key statutory variables would be pollution-based. More precisely, they would specify the rate of change in existing levels of pollution that Congress wishes to achieve during the period until the Clean Air Act once more comes up for congressional reconsideration. Under the revised system, Congress would no longer content itself with mouthing pieties about the need to achieve "reasonable further progress" 50 in environmental protection. It would instead specify, in quantitative terms, how much change is "reasonable" by voting for an $n$ percent reduction (or increase) in the number of aggregate permits that the EPA would be allowed to auction off annually to the nation's polluters. ${ }^{51}$ This single change, we believe, would vastly increase the degree to which the critical questions of environmental policy can be framed in a way that is more transparent to the general public.

This single change, however, can only serve as a first step toward more transparent decisionmaking. Because it is limited to upward or downward adjustment of the aggregate pollution levels permitted under federal standards, it does not allow for more discriminating regulation of particular pollution problems. We see no reason, though, for Congress to content itself with the crude uniformity that Latin commends. For example, within the general context of a $20 \%$ rights reduction, Congress might target certain pollutants for a $40 \%$ reduction, while allowing others to be reduced by only $5 \%$. Similarly, Congress may announce principles concerning the way in which the reductions should be allocated across the nation: For example, should stricter cutbacks be scheduled in areas violating primary or secondary health standards? In ecologically sensitive areas? If so, by how much?

50. See Clean Air Act $\$ 171(1), 42$ U.S.C. $\$ 7501(1)$.

51. See J. KRIER \& E. URSIN, supra note 8 (authors proposed a similar reduction schedule to deal with noncompliance with federal air quality standards under the Clean Air Act). 
Latin insists that such decisions would require Congress to guess about countless contestable matters involving both facts and values. And in this he is surely right. The fact is, however, that these uncertainties already exist, and it is precisely because they cannot be resolved technocratically that they should be framed in a way that invites self-conscious political decision by the Congress. In contrast, the BAT system fails to focus attention on the overall rate at which America should clean up the environment, leaving it to unguided and disjointed bureaucratic and judicial decision in an endless series of BAT inquiries into the "availability" of one or another cleanup technology.

\section{B. Long-Term Strategies: Toward Decentralization and Constrained Cost-Effectiveness Analysis}

While the piecemeal "first-generation" change described in the previous subsection stands on its own merits, it also lays the foundation for a "second-generation" reform in setting environmental goals: Congress would create a statutory foundation for legally constrained cost-effectiveness analysis. Like the first-generation approach, this second-generation statute would express itself in terms of a change-oriented, pollution-based command. Imagine, for example, that the reformed statute mandated a $20 \%$ reduction in allowable pollution levels over the next ten years. In contrast to our first-generation approach, however, the statute would not insist that the $20 \%$ cutback be obtained in each and every part of the country, or in those areas specified by Congress. Instead, the EPA, in conjunction with state and regional authorities, would be given discretion to allocate the cleanup effort. So long as an average $20 \%$ cutback was achieved, the statute would enable administrators to force some areas to cut back up to $30 \%$ while allowing others to cut back only $10 \%$ - provided that they could support these judgments with a thoughtful cost-effectiveness analysis indicating that such variations would lead to cutbacks where they would do the most good in reducing health risks and harm to the environment.

In allowing for limited regional variation, we would be making a final break with the BAT insistence upon nationwide uniformity. We believe that completely uniform goals are seriously dysfunctional, producing too much control in some regions, too little in others, and completely missing special problems in still other regions. A notorious example of mindless uniformity is the 
effluent limitations imposed by the present Clean Water Act, which have required the same level of cleanup by all plants in a given industry, regardless of whether a plant discharges into an ocean or large lake, where the discharges will have little or no effect, or into a pristine river. ${ }^{52}$ This blindness to environmental reality-which is replicated in many other areas ${ }^{53}$-is a parody of the ecological consciousness that should motivate sound policymaking.

Latin, however, opposes every institutional step aimed to take regional variation into account. He attacks our advocacy of constrained cost-effectiveness analysis by supposing that we champion a slide rule determination of economically optimal controls for every source of every pollutant in every region. As we have already noted, we have never advocated such views. Our own study of particular problems, however, has convinced us that it possible to conduct an intelligent debate about whether, for example, it makes more sense to clean up the Delaware River in the vicinity of Philadelphia or whether greater percentage cutbacks are warranted in the ecologically threatened regions of the Delaware Bay. ${ }^{54}$ We fully agree that a narrow economic analysis can

52. See, e.g., Appalachian Power Co. v. EPA, 671 F.2d 801 (4th Cir. 1982). The original system of nationally uniform ambient air quality standards in the Clean Air Act, $\S 109,42$ U.S.C. $\S 7409$, have been transformed into a nonuniform system by subsequent amendments that recognize the difficulty of achieving the standards in nonattainment areas, see Clean Air Act $\S \S 171-78,42$ U.S.C. $\$ \S 7501-08$, and the desirability of prevention of significant deterioration (PSD) in clean air regions, see Clean Air Act $\S \S 160-69$ A, 42 U.S.C. $\S \S 7470-79,7491$. The nonattainment and PSD systems are not based, however, on ecological and health realities, but on the happenstance of BAT implementation and the historical accident that some regions have been less industrially developed, and therefore less polluted, than others.

53. Consider recent congressional proposals to deal with toxic pollution problems by mandatory uniform BAT controls on industrial sources. For example, H.R. 2576, 99th Cong., 1st Sess. (1985), introduced by Congressmen Wirth, Waxman, and Florio, would require the EPA to set stringent BAT standards for 85 named chemical substances, plus any additional substances that might contribute to serious illness. Any citizen could petition the EPA to designate a substance, and the EPA would be required to respond within 180 days. If the EPA failed to set stringent standards for any such substance within two years, the applicable standard would be "no detectable release." This is the use of an indiscriminate BAT strategy with a vengeance, ignoring evidence suggesting that many problems are localized ones in which nonindustrial sources play a major role. See E. Haemisegger, The Air Toxic Problem in the United States: An Analysis of Cancer Risks for Selected Pollutants (EPA-450/1-85-001 (1985)); U.S. Environmental Protection Agency, A Strategy to Reduce Risks to Public Health from Air Toxics (June 1985). See also Harrington, Krupnick \& Peskin, Policies for Nonpoint-source Water Pollution Control, 40 J. Soll \& Water Conservation 27 (1985).

54. See B. Ackerman, S. Rose-Ackerman, J. Sawyer \& D. Henderson, supra note 11. 
only serve as part of an answer to such questions; nonetheless, it is also wrong to imagine that these questions can be responsibly answered without taking costs, as well as benefits, into account. In the end, of course, there will be no escaping the inherently controversial nature of the particular administrative judgments in which cost-effectiveness analysis plays some role. So long as particular agency decisions are made within a larger framework of Congressional policy, however, we believe that they will generate an ongoing public discussion that will, over time, greatly enhance the insight with which the nation confronts its environmental dilemmas. ${ }^{55}$

Latin opposes ecologically and economically sensitive goalsetting exercises on the ground that our empirical understanding of the relevant factors is often rudimentary. But this falsely supposes that cost-effectiveness analysis is useful only when it delivers clear and decisive technocratic answers to policy problems. In our view, such analyses only serve to guide, and not displace, intelligent guesswork. The question is whether we operate under a system, like BAT, which tries to ignore or suppress uncertainty, or whether we operate in a world in which decisionmakers are encouraged to make their guesses as openly and intelligently as they can. ${ }^{56}$ The goal for a second-generation statute is to create a system in which decisionmakers can make limited variations in national priorities in the light of their best guesses about the regional realities they confront.

We entirely agree with Latin, however, that an immediate

55. $\rightarrow$ Reich, Public Administration and Public Deliberation: An Interpretive Essay, 94 YALE L.J. 1617 (1985).

56. Agency officials may fear that more explicit acknowledgment of uncertainty will make agency decisions more vulnerable on judicial review. But the record suggests that this fear is, as a general matter, unfounded. Courts generally respect agency choices that explicitly acknowledge uncertainty. See, e.g., Environmental Defense Fund v. EPA, 548 F.2d 998 (D.C. Cir. 1976), cert. denied, 431 U.S. 925 (1977); Lead Indus. Ass'n v. EPA, 647 F.2d 1130 (D.C. Cir.), cert. denied, 449 U.S. 1042 (1980); Chemical Mfrs. Ass'n v. EPA, 673 F.2d 507 (D.C. Cir. 1982). But cf. Motor Vehicle Mfrs. Ass'n v. State Farm Mut. Auto. Ins. Co., 463 U.S. 29 (1983) (agencies must provide explanations for their decisions and must have adequate studies to reduce key uncertainties. Where agencies suppress uncertainty and seek to base decisions on narrow economic or technological grounds-as the BAT strategy encourages them to do-their decisions are often more vulnerable because the agency's resolution of these technical issues can more readily be shown to be empirically or technically flawed. See, e.g., Portland Cement Ass'n v. Ruckelshaus, 486 F.2d 375 (D.C. Cir. 1973), cert. denied, 417 U.S. 921 (1974); 513 F.2d 506 (D.C. Cir.), cert. denied, 423 U.S. 1025 (1975) (BAT air pollution standards); Weyerhaeuser Co. v. Costle, 590 F.2d 1011 (D.C. Cir. 1978) (BAT water pollution control standards). 
statutory embrace of regional variation would be premature at the present time. Before taking such a step, we must first construct stronger regional institutions than now exist in the overcentralized federal system. We look forward to a day when we might go to any region in the country and find a serious professional staff that could both describe the existing environmental data and models and explain how they propose to improve them over the next five or ten years. Without such an ongoing system of data collection and analysis, there can be little hope of designing regulatory systems which are sensitive to regional ecological and economic realities. Rather than conceiving the construction of such ongoing regional centers as a bit of "finetuning," we think that their absence constitutes one of the principal failures of the present system. ${ }^{57}$ Indeed, if an effort at regional institution-building had been inaugurated 15 years ago with the enactment of the Clean Air and Water Acts, Professor Latin's assertions about the abysmal state of our ignorance would, by now, have less justification.

It is wrong, moreover, to assume that our failure to construct the requisite regional infrastructure is simply a result of tight EPA budgets. ${ }^{58}$ The agency, after all, has spent plenty of time and money engaging in factfinding inquiry regarding the state of the best available technology. The reason for the infrastructural failure is that ongoing careful region-by-region study is irrelevant to the regulatory effort as defined by the present BAT system. To change agency incentives, our reformed law would expressly contemplate a more sophisticated form of auction to commence at some future point in time, say 10 or 15 years after enactment. Under these second-generation actions, different regions of the country could be allowed to cut back permitted quantities by dif-

57. What we propose is the modern-day equivalent of the plan, aired but never pushed in Franklin Roosevelt's second term, for a series of regional TVAs throughout the nation. See B. Karl, The Uneasy State: The United States fkom 1915 to 1945 , $164-67$ (1983).

58. See note 28 supra, for the paltry sums that are presently invested in the effort to monitor environmental realities. It is, of course, no easy matter to create strong regional authorities within our political system. But the TVA experience suggests that the federal government can most readily promote such authorities by endowing them with economic resources and responsibility for their management. By contrast, it is far more difficult to create new authorities with the power, customarily reserved to the national and state governments, to issue and coercively enforce legally binding orders. Accordingly, the shift in tools from BAT commands to transferable pollution permits-the federally created resource which our proposed new authorities would manage-will facilitate the development of regional institutions. 
ferent amounts on the basis of a thoughtful cost-effectiveness analysis; similarly, each regional authority would be allowed to vary cutbacks within its region to account for special conditions. ${ }^{59}$ At no point, however, would we endorse unfettered technocratic cost-benefit analysis. Congress would continue to decide the overall magnitude of natural cleanup and to stipulate an allowable range of variation that could be justified through regional analysis and decision.

\section{Priority-Setting}

Our final set of proposals seeks to correct serious deficiencies in the process by which the current BAT system sets priorities in the light of changing information about environmental realities. BAT discourages intelligent priority-setting for two related reasons. First, the EPA is so overwhelmed by factfinding tasks required to implement a technology-based approach that it has relatively few resources left for exploration of risks posed by new pollutants. Second, BAT imposes heavy bureaucratic costs on the EPA every time it recognizes a new threat to the environment. Once a new pollutant has been identified, BAT requires the agency to exhaust itself with yet another series of never-ending inquiries into the state of control technology in each of the industries that have been discharging the "newly discovered" pollutant and to establish an elaborate set of new industry-byindustry standards. Finally, once a pollutant has been targeted for regulation, BAT automatically requires the imposition of controls to the full extent of available technology 60 -a potentially enormous commitment of compliance resources that may not be justified by the benefits achieved and that is likely to be strongly

59. Of course, if the agency did not exercise its discretion, or if its regional variances did not survive judicial review, the national average (in our example, $20 \%$ ) would apply in the regions affected. Given its long-run perspective, a second-generation statute could also provide a schedule that would contemplate a lengthy period for administrative rulemaking and judicial review.

60. "Available technology" is an elastic concept. In many instances, including most cases of water pollution, technology is available in an engineering sense to eliminate pollution entirely. If we were willing to spend hundreds of billions of dollars, we could have drinking water flowing from industrial waste discharge pipes (although disposing of the pollutants removed from waste streams could present serious problems). Accordingly, most decisions about "available" technology must-implicitly or explicitly - take costs into account. The vice of the BAT strategy is that it ignores this inevitable cost-benefit consideration, or at best buries it, by treating it as an engineering decision about technological feasibility. 
opposed by industry through protracted litigation. It should be no surprise, then, that the EPA has, in fact, been reluctant to expand the number of its pollution targets. ${ }^{61}$

The administrative inertia generated by BAT was, perhaps, of secondary concern so long as one could believe that environmental degradation was the product of a few widespread pollutants, each of which should be controlled to the greatest extent feasible within a period of years. After a decade's practical experience with environmental regulation, however, it should be clear that there are thousands of substances that pose at least some risk and that we cannot deal with all of them simultaneously or impose BAT on all of them within the near future. The defect of the BAT system is that it tends to select, more or less arbitrarily, a relatively few pollutants and devotes enormous administrative and control resources to regulating them to the hilt.

The reforms we have already advocated will create new incentives for the innovative priority-setting that is needed in today's world. First, a statute whose control variables were pollutionbased, rather than technology-based, would encourage a more focused discussion of whether the goals set for different pollutants reflect sensible priorities. Indeed, it is not fanciful to suppose that a risk portfolio strategy eventually might emerge that would explicitly attempt to rank the comparative risks confronted by an EPA or an OSHA and then use cost-effectiveness analysis to determine how available administrative and control resources might best be devoted to minimizing overall risk in a given time period. ${ }^{62}$ Such a strategy need not be limited to conventional air

61. Courts have empowered environmental plaintiffs to force agency action upon presentation of a prima facie case that a currently unregulated pollutant presents a substantial hazard, see Environmental Defense Fund, Inc. v. Ruckelshaus, 439 F.2d 584 (D.C. Cir. 1971), and Congress has codified these rulings in "action-forcing" statutory "citizen-suit" provisions. See, e.g., Clean Air Act § 304, 42 U.S.C. § 7604; H.R. 2576, note 53 supra. While agency inaction is, as we have noted, a serious problem under a BAT regime, the reliance on "action-forcing" through litigation may well be a cure worse than the disease. Such a strategy invites a "pollutant of the month" approach to priority-setting. There is no assurance that the initiatives selected by different environmental groups will result in a sensible allocation of limited administrative and compliance resources. The Supreme Court's recent decision in Heckler v. Chaney, $105 \mathrm{~S}$. Ct. 1649 (1985) may reduce "action-forcing" litigation in the context of regulatory statutes that do not contain citizen-suit provisions. See generally Sunstein, Reviewing Agency Inaction After Heckler v. Chaney, 52 U. CHI. L. Rev. 653 (1985). But this would merely alleviate symptoms of the current BAT system without providing any positive incentives for intelligent priority-setting.

62. In order to reduce some of the administrative and other problems involved in 
and water pollutants. It could also be used, for example, to manage the risks posed by pesticides, chemicals, or hazardous wastes. ${ }^{63}$

Second, the adoption of a marketable permit scheme would dramatically change bureaucratic incentives involved in a decision to target a new pollutant. Rather than ignoring new problems in an effort to avoid BAT burdens, the EPA may well gain additional bureaucratic resources by altering its regulatory priorities, since our proposed statutory reform would reward the agency with a share of any auction revenues that any newly regulated pollutant might generate. Indeed, given their budgetary rewards, a critic might fear that our proposals would generate an equal and opposite danger from the one prevailing under the current regime: Why wouldn't the EPA be transformed into a hyperactive agency, eager to maximize its budgetary revenues by expanding its concern to "pollutants" that do not in fact threaten any serious risk to ecological or human values?

While hyperactivity is a danger, its seriousness should not be exaggerated. After all, every large bureaucratic organization ex-

establishing separate permits and markets for many different pollutants, a "mutual fund" variant of the portfolio approach might be used, where appropriate, to control related pollutants through permits based on a weighted average of volume and risk.

63. Development of such strategies will take considerable time, and there will inevitably remain discrete sources of risk that must be dealt with through command-andcontrol standards or screening procedures. In these limited contexts, regulatory negotiation may be a promising mechanism for promoting more informed regulatory decisionmaking that is sensitive to the magnitude of various risks and the practical problems of managing them.

Latin devotes extensive energies to criticizing those portions of Stewart, note 5 supra, that favor increased experimentation with regulatory negotiation. While legitimately raising many real questions and doubts about the practicality and desirability of regulatory negotiation, Latin commits characteristic errors. First, he supposes that the author regards regulatory negotiation as one of a host of fungible "fine-tuning" mechanisms. The article in fact makes quite clear that regulatory negotiation is a "second best" ameliorative solution, and that economic incentive systems are a basic and preferred alternative to the existing command-and-control system. Second, Latin completely ignores recent practical experience that regulatory negotiation can work successfully to alleviate the worst features of the present adversary, legalistic regulatory system. Contrary to Latin's a priori predictions, the developing experience with regulatory negotiation shows that self-interested business, advocacy, and governmental groups and authorities in fact find negotiated solutions preferable to the expense and uncertainty of protracted legal proceedings. See Lempert, Participants See Value in Reg-Neg's First Flight, LeGal Times, Oct. 10, 1983, at 2, col. 1 (partial success of regulatory negotiation at FAA); Miller, Steel Effluent Limitations: Success at the Negotiating Table, 13 ENVTL. L. REP. 10,094 (1983); L. Susskind \& J. McMahon, Documentation of EPA's Nonconformance Penalties (NCP) Negotiated Rulemaking Demonstration (Report to U.S. EPA, Jan. 1985). 
periences a great deal of difficulty redefining its priorities. Given the reality of bureaucratic inertia, and the fact that industry will continue to resist new initiatives (particularly when it must pay for the right to pollute), ${ }^{64}$ we believe that it is wiser to offer budgetary rewards for innovative priority-setting rather than allow BAT to reinforce bureaucratic reluctance to take changing environmental realities into account.

Our proposed shift in bureaucratic incentives, however, does reinforce the need for a regulatory structure that endorses thoughtful cost-effectiveness analysis in the priority-setting process. Up to the present time, legislators have been able to indulge in apparently absolute statutory prohibitions of all harmful pollutants. This was possible because legislators could count on regulatory lethargy and covert consideration of costs by administrators in defining BAT to blunt statutory calls for an all-out war on pollution. Once a reformed statute has changed the balance of incentives for bureaucratic innovation, we should insist on thoughtful cost-effectiveness analysis before a new pollutant is made the subject of a marketable permit auction. The critical question, in each case, should be whether available administrative and compliance resources will achieve more reduction in environmental risks if they are used to control the new pollutant rather than being used to deal with other pollutants. (For these purposes, costs-like benefits- should not be measured in any mechanical way, and will inevitably involve major social judgments.) If so, the "new" pollutant should be regulated on the basis of the same pollution-based principles that we have elaborated previously; if not, it should not be regulated. Of course, even if an agency refused to list a new pollutant, Congress would be free to force the agency to change its mind the next time the governing statute is reappraised. ${ }^{65}$ Once again, cost-benefit analysis would be subordinated to democratic decision.

Finally, we do not believe that all steps toward more intelli-

64. Industry pressure will also operate to offset potential EPA reluctance, for fiscal reasons, to increase the number of permits for a pollutant already being regulated when new evidence shows that the risks it poses are not nearly as great as originally believed.

65. Given the need for agency flexibility in priority-setting and the dangers of judicial inculcation of the "pollutant of the month" syndrome, we would exclude full-scale judicial review of decisions whether or not to initiate regulatory action against particular substances in all but extreme cases of arbitrariness, provided that a regulatory agency had developed an informed and reasonable process of priority-setting under which the refusal to act in a particular case can be justified. 
gent priority-setting should be delayed until the adoption of some of the more far-reaching reforms we have advanced. It should be emphasized that analysis of costs and benefits is not, as some environmentalists too easily suppose, a code word for regulatory passivity. A stunning counterexample is the EPA's recent decision substantially to eliminate lead additives in gasoline. The key to this decision was an economic analysis performed in the EPA's Office of Planning and Policy Evaluation showing that the move would achieve major health benefits at little or no net cost. $^{66}$ Critics like Latin, moreover, underestimate the amount of information which does exist, but which is ignored by regulators who refuse to confront ecological and economic realities. The EPA, for example, routinely develops information relating each industry's costs of control to the amount of pollution or risk the industry's investment can be expected to eliminate. ${ }^{67}$ It simply fails to use this available information to make the allocation of burdens among industries more cost-effective or to target enforcement resources to the highest-priority problems. Recent changes in the EPA's approach-again, ignored by Latin-show that such steps are feasible. For example, the EPA recently decided not to regulate emissions of acrylonitrile and other toxic emissions under section 112 of the Clean Air Act when analysis suggested that the risks involved were relatively low compared to the more serious problems posed by chromium emissionswhich it did decide to regulate. ${ }^{68}$ Such examples show that it is feasible to do a better job of goal-setting - by introducing costeffectiveness considerations in evaluating control options for different risks and setting priorities more intelligently-even within the existing BAT system.

Steps such as these will not necessarily impose greater burdens on administrators than those that prevail under the BAT approach. ${ }^{69}$ Even when they do involve additional burdens for

66. See note 38 supra.

67. See, e.g., Crandall, supra note 7, at 214-15 (EPA data reproduced in table 8.1).

68. See "EPA to List Chromium Under Section 112, Decides Not to List Four Other Substances," 16 Env't Rep. Current Devs. 236 (June 7, 1985); Harrison, Haig \& Nichols, note 10 supra.

69. For example, in the 1972 Federal Water Pollution Control Amendments, Congress imposed uniform technology-based standards in order to avoid the transaction costs and implementation problems involved in policing environmental quality standards. In order to simplify decisionmaking, the 1972 Act ignored variations in water quality uses and goals. In implementing the Act, however, the EPA felt compelled to consider cost and other variables indirectly in setting BAT standards. This indirect ap- 
administrators, however, this fact alone should not condemn them. The question is whether increased administrative costs are outweighed by greater benefits for society as a whole. The EPA's development of the bubble and tradeoff policies required additional information-gathering, analysis, and other effort. But the payoff has been enormous. The bubble alone has saved over $\$ 700$ million $^{70}$ and stimulated new ways of cleaning up pollution. To focus on administrative costs, without considering the societal benefits of more intelligent regulation, produces penny-wise and pound-foolish public policies. Such myopia is understandable, if not excusable, in politicians. It should not be encouraged by academics who ignore solid evidence that reform can and has worked.

\section{Conclusion}

In urging the fundamental reform of environmental law, we do not mean to disparage the very great accomplishments of the generation that enacted sweeping federal legislation in the late 1960s and early 1970s. Apart from the many unambiguous achievements of this statutory revolution, even the embrace of a BAT approach made some sense as a crude first-generation strategy. During the early days of federal environmental concern, perhaps it was plausible for politicians and other policymakers to suppose that only a few pollution problems were out of hand and that these problems could be "solved" in a short time by an allout war against "pollution." From this perspective, it could seem reasonable to try to force everyone to adopt the best available technology everywhere.

Our complaint is not with the statutory draftsmen of the early 1970 s, but with lawyers of the 1980s who fail to put these early statutes in historical perspective. ${ }^{71}$ Experience with more than a decade of intensive regulation emphasizes that the environmental risks we confront are numerous and vary widely in serious-

proach caused the EPA to set separate standards for over 500 different industry and subindustry standards, a majority of which were challenged in court. Long delays in implementing the statutory scheme resulted. See also R. MELNICK, supra note 9, at 193-205 (chronicling problems in adjusting the uniform federal air quality standards to differing local and regional circumstances).

70. See note 37 supra and accompanying text.

71. For another effort to put these statutes in perspective, $\rightarrow$ Elliott, Ackerman \& Millian, Toward A Theory of Statutory Evolution: The Federalization of Environmental Law, $1 \mathrm{~J}$. LAw, Econ., \& Org. 313 (1985) (forthcoming). 
ness. Our strategies for managing these risks must set intelligent priorities, make maximum use of the resources devoted to improving environmental quality, encourage environmentally superior technologies, and avoid unneeded penalties on innovation and investment. Rather than wringing our hands helplessly before these complexities, the challenge is to incorporate maturing perceptions about our regulatory problems into the evolving legal structure-and help our fellow Americans build a system that will not only save many billions of dollars a year, but make environmental law more democratically accountable and bureaucratically effective. It is time for environmental lawyers to stop celebrating the statutory revolution of the 1970 s and to start building a statutory structure worthy of the year 2000 . 